\title{
Gender, Missions, and Maintenance Activities in the Early Modern Globalization: Guam 1668-98
}

\author{
Sandra Montón-Subías ${ }^{1,2}$ (D)
}

Published online: 13 August 2018

(C) The Author(s) 2018

\begin{abstract}
This article proposes that early modern globalization took shape through the global circulation of gender ideologies, sexual politics, engendered technologies, and engendered knowledge. It does so by exploring the early years of Jesuit missions in Guam (Mariana Islands) and describes mission policies as engendered sexual policies that fostered the emergence of a new sex/gender system within indigenous Chamorro society. These policies targeted, among others, the sphere of maintenance activities. This concept highlights the foregrounding nature of a set of routine everyday practices that are essential to social continuity. Guam offers an interesting case study to discuss how gender transformations were performed and implemented on the ground, and what they entailed for those who experienced them.
\end{abstract}

Keywords Gender-Early modern globalization · Maintenance activities · Colonial Guam - Jesuit missions

\section{Introduction}

some weddings were made of Spaniards and Indians alike, with some of the bestraised Mariana girls from the girl's schools; among these a particular one was most notable, at the residence in the village of Orote. Here, and following the example of another married peer, one such girl made up her mind to get married at the Church. Aware that if her parents or relatives were to find out they would try to hamper such plans, - to give her away or even sell her off to one of the

Sandra Montón-Subías

Sandra.monton@upf.edu

1 Departament d'Humanitats, University Pompeu Fabra, Ramon Trias Fargas 25-27, 08005 Barcelona, Spain

2 ICREA, Pg. Lluís Companys 23, 08010 Barcelona, Spain 
urritaos -, she secretly confided her decision to the missionary, who happened to be venerable Father Sebastian de Monroy. She solved all the difficulties posed by him, and even said that, if necessary, she would break up with both her parents and her people to live by God's Law. In view of such resolution amid the Indians' natural proneness to inconstancy, the father reassured her good intents and immediately oversaw the fully solemn administration of the Holy wedding on the occasion of a festivity. This he did so that the Indians, placed before the Sacred Rites and ceremonies of the Holy Church, would recognize the barbaric character of their own, and the invalidity of their weddings, which are undeserving of such a name, for they lack any perpetuity, as has been described elsewhere (García 1683: 534-535, my translation).

A number of different scholars have cogently connected the origins of the first globalization to the processes of expansion, conquest and colonization initiated by the Hispanic Monarchy at the end of the Middle Ages (e.g., Aram and Yun-Casalilla 2016; Giráldez 2015; Gruzinski 2004, 2012; Marks 2002; Quijano 2000; Wallerstein 1974). However, the idea that this first globalization also took shape through the global circulation of gender ideologies, sexual politics (sensu Millet 1972), engendered knowledge and engendered technological transfers has not yet been sufficiently explored.

Like many others (e.g., Deagan 1974; Lugones 2007, 2008; Segato 2015; Stearns 2006; Tarble de Scaramelli 2011; Voss 2008a), I consider gender a vital factor in understanding both colonialism and the early modern globalization. Colonialism brought into coexistence groups of people with different sets of social relations between men, women, and others, and with different sex/gender systems, sometimes of a gargantuan cultural distance. This had dramatic consequences for persons of all ages and conditions around the world, and often disrupted those local gender understandings which proved incompatible with the ones brought and/or imposed by colonial agents. Through focus on the material culture by which these processes were both constructed and displayed in specific colonial situations, archaeology is contributing to a better understanding of this first "gender globalization."

In this article, I will present one of such situations: the incorporation of Guam (Mariana Islands) into the colonial network of the Spanish empire as part of the seventeenth century worldwide expansion of Jesuit missions (Fig. 1). Understood as a "civilizing" enterprise (sensu Fanon 1952), the colonization of Guam targeted from its very outset both gender arrangements and maintenance activities. The latter is a concept used in archaeology to highlight the foregrounding nature of a set of practices of everyday living that are essential to social continuity (González et al. 2008). Through forced restructuration of living spaces, children's socialization, foodways, careways, dress and corporeal habits, kinship, healing practices and sexuality, Jesuit missionaries sought to dismantle native Chamorro lifeways. Chamorro (Chamoru in the local language) is the name that the indigenous people of the Marianas Islands give themselves today. In this paper, I will also refer by it to indigenous populations present before and during the Spanish colonization, although Spanish documents mention that Chamorris or Chamoris was the name given to local leaders (e.g., Archivo General de Indias [hereafter AGI], Ultramar, Leg. 562). 


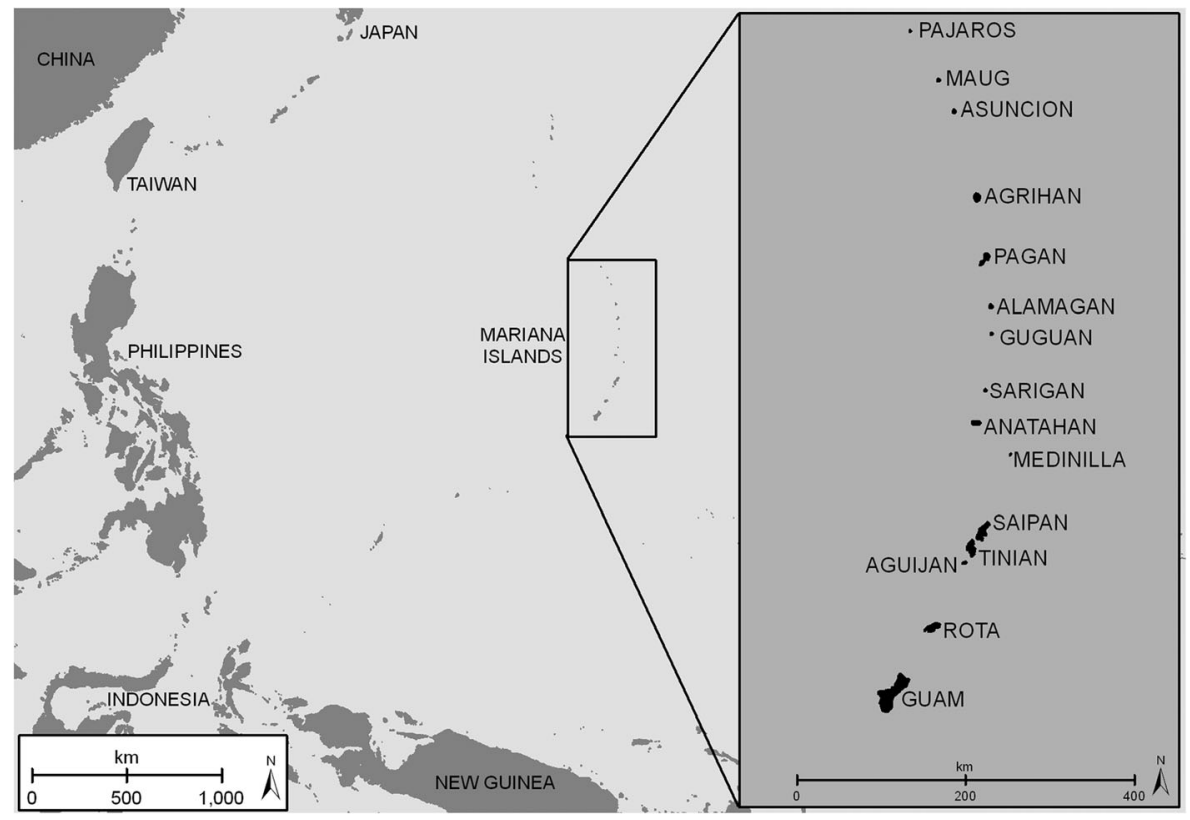

Fig. 1 Map of Guam and the Mariana Islands in the Western Pacific, courtesy of Mike Carson

I focus on the first years of colonization: from 1668 to 1698 . This is the period known as the Spanish-Chamorro wars, when locals underwent the most dramatic changes. The concept of the Spanish-Chamorro wars has been recently revisited and challenged under the idea that colonial violence was far away from the image that the concept conveys (Hezel 2015). While this may be true of physical violence, it is important not to lose sight of the ontological violence that forever dismantled the traditional lifeways and beingways of native Chamorro.

My aim is to present the connections between colonial processes, material culture (including the body) and the construction of sex/gender systems through the interpretation of the specific case of Guam, and to show the day-to-day materialization of more general gender-global changes. I proceed in five main steps. First, I present some brief notes on the sources I have used. Second, I situate my case study within historical perspective. Third, I shortly discuss the concept of Maintenance Activities to clarify why they were targeted by missional policies. Fourth, through focus on the reorganization of living spaces, children's socialization, and emerging dresscapes, I discuss how gender transformations were performed and implemented on the ground, and what they entailed for the people who experienced them. Finally, I discuss how colonization promoted gender inequality and women's subordination.

\section{A Brief Note about the Sources Used}

For the purpose of this article, I have converged information provided by written sources and material culture. Both present problems and biases, but, as a whole, they convey an idea of lifeways both before and after colonization. A long-term approach to 
colonialism has been emphasized to understand this phenomenon in its full breadth (e.g., Lightfoot 1995), and I share this philosophy. Thus, the evidence used here spans precontact contact, and the first period of permanent colonization, therefore bridging the long-debated prehistory/history divide (e.g., Connah 1998; Fredericksen 2000; Little 1994; Wilkie 2005). Historical documents go from Pigafetta (1524) to William Dampier (1697) through the Boxer Codex (written in the late 1500s), Esteban Rodríguez (1565), Juan Pobre de Zamora (1598-1603), Oliver Van Noort (1602), Peter Coomans (1673), Francisco García (1683), Gabriel de Aranda (1690), and some of the corresponding Jesuit Annual Letters (Litterae annuae) sent from Guam to the Father General in Rome. If sources prior to permanent colonization bring us closer to precolonial life styles, Jesuit colonial relations and annual letters both add and emphasize those changes that took place during missionization.

These documents are of a very complex nature (see Coello et al. 2012; Rubiés 2017) and are also clearly engendered. To begin with, they were all written by men. They share a Eurocentric - and thus androcentric- perspective, with the concomitant sexist and heterosexist biases. It would not be surprising, for instance, to find a lesser commitment to female issues, or a greater inaccessibility, misinterpretation and lack of understanding of them (as even today anthropological fieldwork shows substantial differences depending on the informants' gender). As an extreme but illustrative anecdote, we could recall García's mention of friar Sebastian de Monroy (1683:548), who "whenever he walked past women would not even take his eyes off the ground so as not to see anything" (my translation).

Equally important in the case of Jesuit literature is to not lose sight both of its apologetic ambition and its self-legitimating function in raising constant funds for the mission, which might have caused intentional aggrandizements and deliberate omissions. In addition, and rather interestingly, some of these documents were written by friars that never visited the islands, but based their writings on either primary sources or previous relations. In a world with no such notion as intellectual property, the recurrence of the same sentences and even paragraphs in different documents casts doubts over whether the same situation was often observed or just copied and passed downthe-line.

Regarding material culture, I have used both archaeological evidence and information that can be inferred from texts. Although archaeological work also presents biases and problems -fieldwork mainly targeted at precontact sites, sparse systematic excavations or difficult access to reports resulting from salvage- I want to underline the uttermost importance of material culture and the body to understand the full and profound implications that colonial processes had on native Chamorro. In such oral societies as precolonial Guam, both are fundamental in shaping the self and mediating with others and the world (e.g., Hernando 2017; Moragón 2013; GonzálezRuibal et al. 2011).

\section{The Historical Background}

March 1521 was a fundamental month to the islanders of Guam. It was then, within the framework of the Magellan-Elcano circumnavigation, that the first contact between Oceania and Europe transpired in their waters. However, the permanent colonization of 
Guam began only in 1668, when the first mission was established in Hagåtña under the leadership of Jesuit Diego Luis de San Vitores. Since then, and for years to come, dramatic changes were to take place, including a process by which the native population was forcibly concentrated in a reduced number of villages or towns (e.g., Solorzano 1683 in Lévesque 1996a: 22, 68), and known in today's scholarship of the island as La Reducción.

Needless to say, human settlement in the Mariana Islands had commenced much earlier, around $1500 \mathrm{BCE}$ according to current archaeological evidence (Athens et al. 2004; Carson 2012, 2014; Hunter-Anderson and Butler 1995; Kurashina and Clyshulte 1983). Later changes in the archaeological record - around 800/900 CE-have been interpreted as the emergence of Latte period societies (Carson 2012; Hunter-Anderson 2011; Russell 1998). These were the groups that received Magellan's crew in 1521, and who underwent colonization from 1668 onwards.

Despite the fact that the Latte period constitutes most archaeological work in the Marianas today (more than 90\% according to Carson 2012: 3), there are still many gaps to be filled. We know that Latte Chamorro were oral communities who made a living from horticulture, fishing, and gathering shellfish and the jungle (see Dixon et al. 2010; Carson 2012). We also know they constructed Latte buildings, which have long drawn the attention of both the scholar and lay public, and which are presently enshrined as icons of Chamorro identity (Fig. 2). Of a rectangular plant, they consisted of stone foundations made of shafts (haligi) and semicircular capstones (tasa) with rooms atop constructed in perishable materials (Carson 2012; Hornbostel 1924-25; Laguana et al. 2012; Reinman 1966; Peterson 2012; Russell 1998; Thompson 1940, 1945). Unfortunately, such aspects of their social structure as the existence of different social positions of power and their matrilineal character - two of the most recurrent issues in the historiography of Marianas - are not as clear.

Different scholars agree that Chamorro societies were of matrilineal descent (e.g., Atienza and Coello 2012; Hunter-Anderson 2011; Hunter-Anderson and Butler 1995; Peterson 2012; Souder 1992; Thompson 1945, 1947), although the social implications

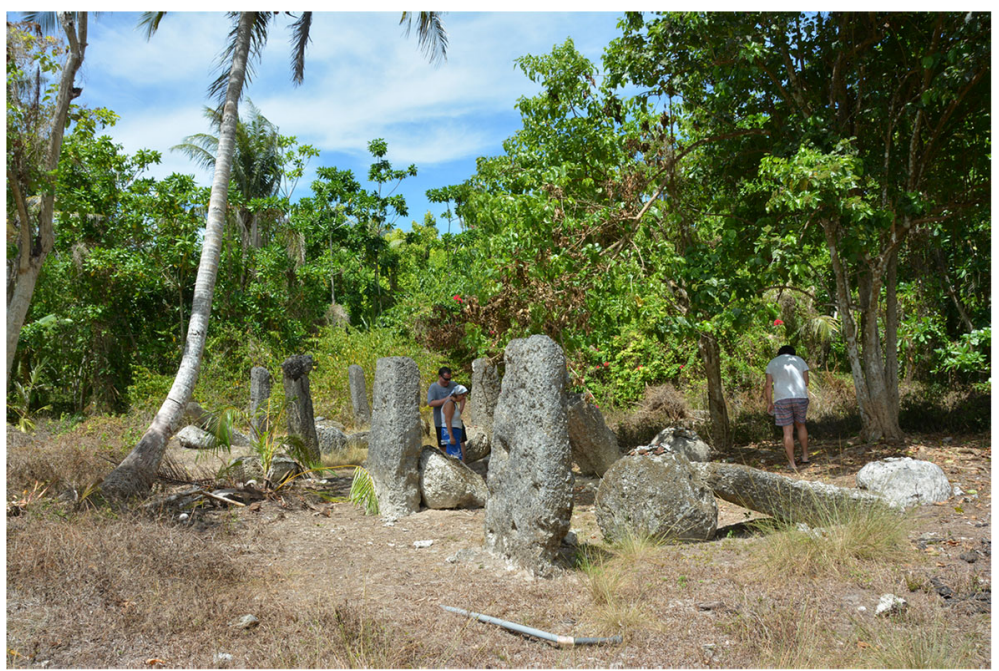

Fig. 2 Remains of a latte building at Inapsan (Guam), photograph by author 
of this feature remain unclear. Such mentions in documents under scrutiny are vague and related to inheritance by the brother or the nephew of the deceased, and not the son (e.g., García, 1683: 199; Ledesma 1670: 4; Pobre de Zamora 1598-1603, in Martínez 1997: 451). Coomans (1673, in Lévesque 2000: 18) even clarifies that the nephew is the brother's son, and that no woman is allowed to inherit unless there is no man available to do so. Equally ambiguous is the evidence that refers to differences in social power. Pigafetta, a member of Magellan's crew, wrote that there were no lords among them (in de Riquer 1999: 177), but other sources identified a group of leaders referred to as principales, which could be translated into English as "the main ones." Described as enjoying some social advantages but having very limited power, they have been interpreted as people with high status or socially preeminent community leaders (Driver 1983: 208). Documents also make it clear that there was no single inter- or intra-island political authority (e.g., García 1683: 201-202; Ledesma 1670: 3; Pobre de Zamora 1598-1603, in Martínez 1997: 446).

Information provided by archaeology is not conclusive either. Unlike Graves (1986), who argues that the different sizes of Latte buildings is evidence of social stratification, most scholars propose a more horizontal social organization and interpret size differences as being due to different functions (e.g., Cordy 1983; Craib 1986; Dixon et al. 2006: 56; Laguana et al. 2012: 87; Peterson 2012: 202-3). Data about tombs, bodies and material culture do not seem to support rigid social hierarchy either (see also Russell 1998: 139-151; Hunter-Anderson and Butler 1995: 21; Peterson 2012: 203; Stodder et al. 2015). However, more systematic excavations and studies of Latte settlements and cemeteries are needed to allow a more robust inter- and intra-island comparison.

According to written sources, when missionaries first arrived in Guam they were welcomed by principales. However, and unsurprisingly, cordial relations came to an abrupt end when missionaries sought to disrupt all those aspects of traditional life incompatible with their own self and world understandings (see also Thompson 1947: 293). The first episodes of conflict (two months after the missionaries' arrival) took place on the neighboring island of Saipan, but hostilities soon spread to Guam, Rota and Tinian, and continued for some 30 years (Hezel 2015). In the 1680s, governors José de Quiroga and Antonio Saravia enforced La Reducción deploying a military force mainly made up of Mexican and Philippine soldiers. La Reducción dislocated natives from their traditional villages into a far more reduced number of towns, situated mainly in southern Guam (Brunal-Perry 2009; Farrell 2011: 189; Hezel 1989; Russell 1998: 305).

To place the colonization of Guam in global perspective, we need to frame it within the modern worldwide expansion of Jesuit missions (Banchoff and Casanova 2016; Clossey 2008; Coello et al. 2012; Molina 2013; Prosperi 1992). Understood from the outset as a "civilizing" project (sensu Fanon 1952, and see also Molina 2013; Selwyn 2004), the Marianas and Guam were more than a military, economic, or geostrategic target: above all, they were part of a broader soul-saving project (Thompson 1947: 193) that sought to extend Christian "civilization" to as many people as possible. This is a type of process that fits well into what Latin American decolonial scholars- drawing on Fanon's legacy have called "coloniality" (e.g., Lander 2000; Lugones 2007; Maldonado-Torres 2007; Quijano 2000; Segato 2015). In Guam, this process brought about the 
emergence of a new sex-gender system and was enacted through specific sexual politics (sensu Millet 1972) and the rearrangement of maintenance activities.

\section{Maintenance Activities in Early Colonial Guam}

\section{Colonizing Maintenance Activities}

Initially catalyzed by feminist challenges to unveil sexist biases in the archaeological discipline (Bertelsen et al. 1987), and in close proximity with developments in feminist, gender, and feminist household archaeology (Conkey and Gero 1991; Hendon 1996; Tringham 1991), the concept of maintenance activities has been used to underscore the structural nature of a set of quotidian, repetitive and routine tasks required for the continuity and wellbeing of any human group (e.g., González et al. 2008; Montón-Subías and Sánchez Romero 2008; Picazo 1997). In a broad sense, these activities are connected to care-giving (from birth to death), to feeding and food-processing, to textile manufacturing and to hygiene, health and healing. They also include the socialization of children, and the fitting out and organization of residential and related spaces. Carried out recurrently in the same spaces, usually within the bounds of the settlement or its immediate vicinity, Maintenance Activities cements the group's cohesion through the strengthening of its basic bonds. As they unfold, they delineate a concrete form of everyday logic, which may vary according to different chrono-spatial coordinates, but which invariably plays a structural role everywhere. This structural role guarantees the reiteration and recurrence of the group's activities, and/or channeling changes into new reiteration and recurrence patterns (González et al. 2008).

Historical and ethnographic evidence shows that Maintenance Activities have predominantly been women's domain. However, the lower the differences in gender asymmetries, the more likely they are to be carried out by men too. Could precontact Chamorro have constituted one such case? According to written sources, women and men would have shared certain activities, but not others. Women would have been in charge of taking care of young children, cooking, gathering shellfish, and weaving. They would have also played a leading role in funerals as mourners. Men would have been responsible for canoe building and making fishing tools, deep-sea fishing, interisland trade and sporadic warlike practices. Both men and women would have shared children's socialization, work in garden plots, and fishing in the lagoon -also with the participation of children (e.g., Pobre de Zamora 1598-1603, in Martínez 1997: 441$444,451)$. It thus seems that, while men would have participated in some maintenance activities, they would also have been involved in activities that implied greater movement and risk, and thus be less restricted to the immediate bounds of the settlement; a pattern consistent with those described in ethnoarchaeological studies (e.g., Hernando 2008).

So far, few archaeological works have focused on gender and maintenance activities on the Mariana Islands (but see Bayman et al. 2012a, b; Dixon et al. 2006). Although conducted in Tinian, one of the islands north of Guam, the excavation of six habitation sites supports the possibility of communal daily life in terms of sharing such outdoor activities as food preparation, cooking, food and water storage, eating, tool manufacture/use and human burial (Dixon et al. 2006). Fieldwork undertaken in 
two contact period Latte buildings at Ritidian, in Guam, revealed a greater proportion of material culture related to culinary, textile and ceramic manufacture inside one of these buildings, as well as fishing gear and tools related to canoe-building in the other (Bayman et al. 2012a, b). In any case, in terms of presence and absence, both types of activities were featured in both buildings. Bayman et al. (2012a: 268) claimed segregated spaces for men and women's activities, but also pointed out that Chamorro matrilineal societies might possibly have presented a less strict sexual division of labor. In any case, as was also noted, this was the first excavation to have recorded such a differentiation, so caution is recommended until future excavations can confirm or refute this interesting hypothesis.

Conflating archaeological and written evidence, we can envision communities where some tasks were complementarily divided between men and women, while others were shared in the absence of full-time specialists, an elaborated kinship system and a strong sense of community bonding. Only "macanas," probably an equivalent to shamans and considered by native Chamorro to be very wise men with special powers such as healing, telling the future, propitiating good deep-sea fishing, making rain and mediating with ancestors (e.g., García 1683:204; Pobre de Zamora 1598-1603, in Martínez 1997: 449), might have had different roles in these tasks (see also McNeil 2005: 314; Russell 1998: 153; Thompson 1947: 169171, 197). Otherwise, everyone carried out the same tasks (although see Heatcothe et al. 2012 for possible semi-specialist builders in Tinian). Even principales are described as performing the same activities, eating the same food, and presenting their body in the same vein as the remaining of the group. This picture is also consistent with a scenario of oral societies with a low degree of social hierarchy (see also Russell 1998: 147).

Different works in the social sciences and humanities have been discussing orality over a long period of time (e.g., Havelock 1988; Hernando 2002, 2008, 2017; Goody 2006; Olson 1986, 1996; Ong 1982). For the purpose of this paper, and to better understand the consequences that colonization brought to Guam, let me recall five important characteristics endorsed by oral societies with low or non-existing levels of social hierarchy: 1) the self is constructed through relations with others in the group and is thus based on an indissoluble bonding with their group; 2) the self is constructed and represented through material culture and the body in the absence of a conceptual split between mind and body; 3) men, women and others tend to preserve their lifeways through the repetition of the same activities, which are considered to have been transmitted from generation to generation by - usually worshipped - ancestors (referred to as aniti in Guam's documents); 4) stability is thus valued over change; and 5) space is self-referential, very limited and densely filled with feelings and emotions because everything that lives within it adopts a human behavior (e.g., Hernando 2002, 2008).

Equally important, in such societies, the gap between the social value attached to maintenance activities and other types of activities is usually non-existent, or at least very minor if compared to those cases with strong differences in social power and clear gender asymmetries, where maintenance activities become women's preserve and retain little prestige. We cannot tell whether such a breach would have eventually appeared in Guam because Jesuit missionaries dismantled traditional lifeways and their underlying logics (Montón-Subías et al. 2018). 
Archaeological and anthropological studies have also shown how mission policies targeted daily life in different parts of the globe (e.g., Comaroff and Comaroff 1986; Jaulin 1973; Lightfoot 2005; Panich and Schneider 2014; Silliman 2001; Wernke 2012), especially in the light of Bourdieu's habitus (1972). However, maintenance activities are more than just an important part of daily life; maintenance activities configure the very structure that enables daily life, and upon which their logic operates. A type of logic that is associated to specific values and specific self and world understandings, and that, in Guam, were incompatible with those of the Jesuits. It is thus easy to understand why, almost since the first moment of effective colonization in 1668, quotidian maintenance activities, along with the habitus they entailed, were made the target of missional policies. Their ultimate aim was to impose new ways of being (both social and personal) by de-structuring preexisting ones.

The disintegration of maintenance activities was orchestrated through a variegated set of interconnected mechanisms. From landscapes to spindles and metates, through dress, ornaments, Catholic paraphernalia, churches or schools, new material worlds emerged to construct and represent the new colonial situation. In this paper, I will focus on sweeping changes undergone by residential space, the socialization of children and bodily habits, dress and textiles. All three provide good examples of how patterns of reiteration and recurrence were substituted for others, and how material culture participated both constructing and displaying these processes. They are also a good example of what changes promoted by colonial policies meant to ordinary people.

\section{Residential Spaces and Reducciones}

The disruption and reorganization of daily residential spaces through the forcible concentration of population in reducciones was one such mechanism. Drawing on experience acquired in other areas of the empire, La reducción began to be implemented in the early 1680s. By the end of the seventeenth century most of the population in Marianas had been relocated in the south of Guam.

According to the written sources, native populations had previously lived in small to medium-sized villages scattered across the islands, but with a higher concentration of houses on the shoreline (Coomans 1673 in Lévesque 2000: 7; García 1683: 197). While some archaeologists support a greater number of Latte sites near the coast (e.g., Laguana et al. 2012: 83), others point in the opposite direction (Peterson 2012: 197). A close look at the maps resulting from the first archaeological surveys on the island (Hornbostel 2; Reinman 1966), reveals the ubiquitous character of latte sites, both on the coast and inland, wherever good opportunities for human settlement occurred (Carson, pers. comm.).

A result of communal building, thatched lattes were particularly praised as the best and cleanest native houses ever seen in contemporaneous written sources (e.g. Coomans 1673, in Lévesque 2000: 17; García 1683: 197; Pobre de Zamora 15981603, in Martínez 1997: 445; Rodriguez 1565: 392, in Kerr 2013). They are described as places for cooking, weaving, resting, storage, and sheltering canoes, but some texts situate all these activities in the same building (e.g., García 1683: 197) while others describe different types of independent buildings (e.g., Coomans 1673, in Lévesque 2000: 11-12; and see also Laguana et al. 2012; Thompson 1945: 36). To the previous functions, we should add the much scorned "public houses" that bachelors had in each 
village, where unmarried men (urritaos), lived together with unmarried women (rajaos) sometimes marrying later (e.g., Coomans 1673, in Lévesque 2000: 17-18; García 1683: 201, 241-242; Ledesma 1670: 25; San Vitores 1671). Information about these houses is both limited and probably highly biased by missionaries' head-on opposition to them (Montón-Subías et al. 2018; Moral de Eusebio 2016; Russell 1998: 149). It seems that urritaos offered valuable goods to women's families (e.g., Coomans 1673, in Lévesque 2000: 19; García 1683: 201), so it has been hypothesized that they might have configured a system by which Chamorro families acquired goods and men acquired wives (Bayman and Peterson 2016: 244). It has also been suggested that bigger lattes could correspond both to these "public houses" and canoes' shelters (Dixon and Gilda 2011: 80; Russell 1998: 225-226; Thompson 1940: 461).

Importantly, the native Chamorro buried some of their deceased under, between or in front of lattes, hence making the spaces inhabited by the living suitable to also "house" their dead, a fact described in coetaneous sources (e.g., Pobre de Zamora 1598-1603, in Martínez 1997: 491; Coomans 1673, in Lévesque 2000: 17) and corroborated by archaeology (e.g., Hornbostel 1924-25; McNeil 2005; Stodder et al. 2015; Thompson 1940, 1945). Pobre de Zamora (1598-1603, in Martínez 1997: 491) narrates the story of a Principal that was buried in front of his brother's house, and also adds that common people were buried in front "of the most prestigious relative's house" (see also Driver 1983: 216). Although more comprehensive archaeological mortuary studies are needed, those conducted upon Tumon Bay Hyatt site -in use from $411 \mathrm{CE}$ to 1699 CE- demonstrated no significant sex differences in the number of burials or health, and used cranial parameters to defend burial in kin groups or lineages (Stodder et al. 2015). A tradition of burial following maternal lineage was launched as a working hypothesis based on heritable non-metric traits found in two female skulls in burial group C. Taphonomic post-depositional processes prevented clear associations between burials and grave goods, but post-mortem disturbance for bone acquisition and secondary burial were also documented in both male and female graves (see also McNeil 2005: 308). Secondary burials consisting only of individual skulls have been documented in other latte cemeteries (e.g., McNeil 2005: 308). Interaction with the dead was also reported by written sources in the form of human-bone use for weapons (e.g., Coomans 1673, in Lévesque 2000: 25; García 1683: 200) and by the presence of venerated skulls inside the houses (e.g., de Aranda 1690: 220; Coomans 1673, in Lévesque 2000: 17; Pobre de Zamora 1598-1603, in Martínez 1997: 448-449). This highlights that the continuity between physical and symbolic spaces of life and death is manifested in the use given to dead bodies.

Unfortunately, no reducción has yet been excavated, and the written information available is meager. García (1683: 584), for instance, mentions that the most adequate places were chosen to form larger populations so that they could be managed more easily (1683: 584). But reducciones were more than mere administrative centers to control mobility and avoid uprisings. Reducciones were designed as true "civilization" centers to colonize native lifeways and "settle" a new mode of being (for similar examples, see Comaroff and Comaroff 1986: 13; Jaulin 1973: 136; Van Valkenburg 2017; Wernke 2012: 204; Zuluaga 2014). Important institutions of Chamorro life (such as the "public houses") were forbidden, and the Christian/European's own (such as the indissoluble marriage and the monogamous nuclear family) imposed. The planning out of a new spatial logic and the constructing of buildings alien to traditional cosmovisions 
to house churches and schools were the most physical and visible correlate of the colonization of indigenous space.

Let me restate here the meaning that space must have had for oral Chamorros to understand better what this forced resettlement meant. In oral societies, with no maps or writing, people's perception of world size and boundaries coincides with the space that is personally experienced (Bourdieu 1990; Goody 2006; Hernando 2002, 2008; Thornton 1980). Space is thus self-referential, more limited, and encrusted with emotions and feelings (Hernando 2002, 2008). It is of utmost importance in selfformation, and not just a passive scenario where to act, move, or extract resources (Hernando 2002; Lefébvre 1974; Low and Lawrence-Zuñiga 2003; Massey 1994; Soja 1993). For some Chamorro, reducciones must have been close to their native villages, but for some others, they were located kilometers away, even on a different island, in places they had never experienced before, and far away from the land of their worshipped aniti. An anecdote told by Laura Thompson (1947: 99) captures the significance of this well. Referring to the toponomy collected by Gertrude Hornbostel in Rota before WWII, Thompson recalls that, despite the island's small size, she found that no native had ever visited the entire island, and she needed five guides to cover the whole island, which was divided in different districts inhabited each of them by the ancestral spirits of a different lineage.

It is precisely this emotional attachment with space that was cut deep by $L a$ Reducción (see also Xaramillo 1680, in Lévesque 1996b: 312 for a more empathic understanding of what reducciones meant to natives). While for colonial agents space was a bi-dimensional reality, in transposition from its perception through maps, from which they feel emotionally detached, for Chamorro inhabitants their space was a multidimensional reality of human behavior with which all kinds of emotional bonds were established. If for colonial agents the concentration of population in reducciones was mainly a politico-religious enterprise that dis-located Chamorros from their ancestral lands, what was put a stake for the Chamorros was the very structure of their own world; the human ordering they made of their environs in the course of everyday interactions, practices and experiences.

Needless to say, there were material continuities - and thus material links - with the past. Part of the vernacular architecture remained in a less majestic version of latte dwellings: pole-and-thatched houses over hard wood uprights, which were still in use in the twentieth century (Dixon et al. 2017: 214; Flores 2011: 74; Laguana et al. 2012: 85, 88, 107; Thompson 1940: 462) (Fig. 3). However, their foregrounding logics were different, as was their spatial integration in the settlement, which became planned in a different way (see for instance Dixon and Gilda 2011). Many of the latte's previous spatial arrangements and functions, such as "public houses" and canoe shelters, were also lost.

Cults celebrated inside the houses also changed their shape in congruence with the new Christian beliefs: ancestors' skulls were forbidden and substituted by the body of Christ in the form of the Christian cross (see also Coello 2011: 730). Importantly, dwellings would no longer combine the spheres of life and death. If before the areas used by the living were considered the ideal locations to bury their dead, now a differentiated spatiality between life and death was demarcated (see also Coello 2011: 730). The new Christian funerary protocol prescribed that the only house suitable to also house the dead was the house of God, preventing any possibility of physical 


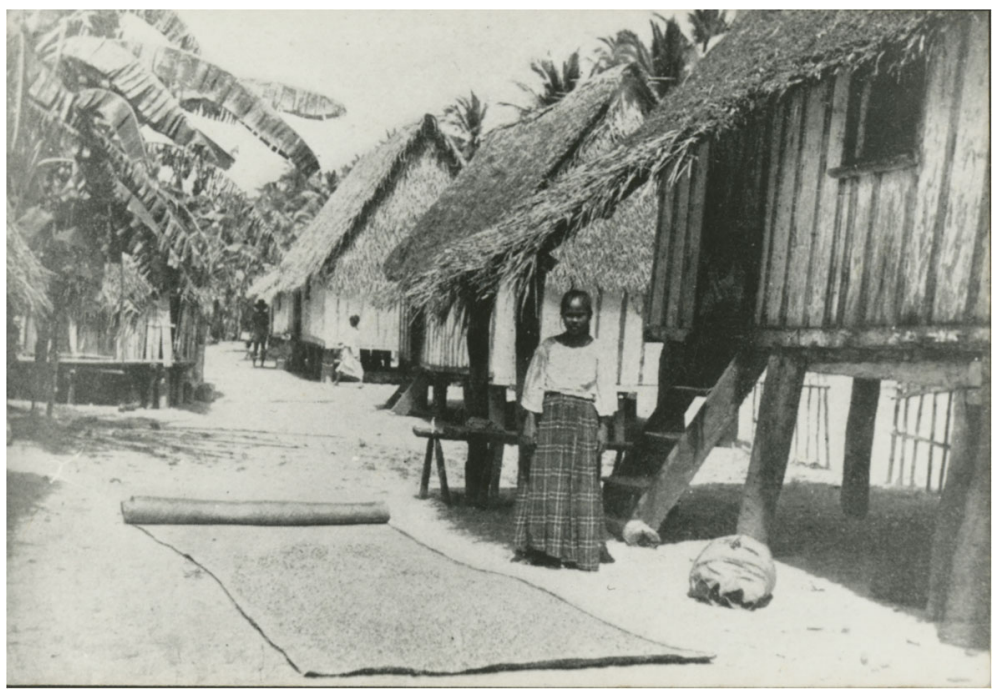

Fig. 3 Pole-and-thatched houses from Hagåtña ca. 1910. From the collection of the Richard F. Taitano Micronesian Area Research Centre, GC 10-14

interaction with the deceased (for conflict and opposition to burials in churches before La Reducción, see Coomans 1673, in Lévesque 2000: 17; García 1683: 221). Funerary spaces thus became differentiated and located in close vicinity of the church, the new architectural form that would now emerge as the new locus of community life and community death (see also Coello 2011: 730; Dixon et al. 2017: 213) (Fig. 4).

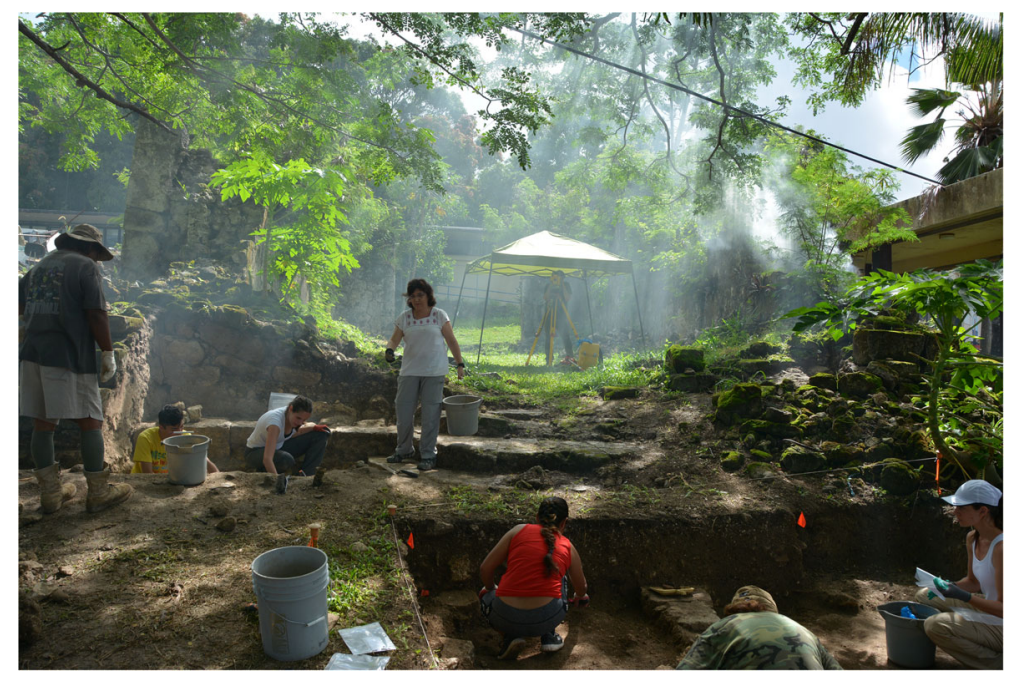

Fig. 42018 excavations at the church and cemetery of San Dionisios (Umatac, Guam) conducted in the framework of the archaeological project ABERIGUA. Photograph by Laura Trelliso 
Incorporating Colonialism: Children's Socialization and the Construction of Engendering Schools

Children's schooling was probably the most effective measure implemented by the Jesuits to "act over the future" (Jaulin 1973: 167). It is through children's socialization that cosmovisions, belief systems, social values and patterns of how to act and behave in society are transmitted over generations. It is thus easy to understand why the Jesuits had schools or seminarios built almost on their arrival, and why they began -in their own words- "hunting" children, the yeast that would make the dough grow (García 1683: 240). Parental attitudes ranged from stiff opposition (e.g., Gabriel de Aranda 1690: 377) to collaboration (e.g., Gabriel de Aranda 1690: 309-10), but once the younger generations were socialized in the Christian values, the entrenchment of Christianity was secured for the centuries to come, even to this day. As one of Ledesma's (1670:13v) sentences acknowledged: "grown and elderly men alike make good Christians once they have been good Christians as children" (my translation).

Historical documents offer a glimpse of children's socialization before colonization. In the hands of parents, families and the very communities -which are described as having a great love for kids (e.g., Pobre de Zamora 1598-1603, in Martínez 1997: 444)-, children learned "to live by living" (Thompson 1947:8), by undergoing a socialization process aimed at securing traditional lifeways and continuity. With the arrival of the mission, children's socialization was partly "externalized" through formal schooling, and became spatially segregated and enclosed in specialized buildings for the first time in Marianas. Annual Letters list the new array of material culture children became exposed to: textbooks, cathecisms, paper, pens, guitars, lyres and other musicals instruments (Real Academia de la Historia [hereafter RAH], Cortes 567, Leg 10 9/2676, doc. 4, p. 1v).

Coetaneous descriptions of schools are meager, and no archaeological excavation has ever been conducted on them either. Before La reducción, they were probably constructed closely following the vernacular tradition and placed in the vicinity of the church (e.g., de Aranda 1690: 309). Most probably, schools evolved architecturally in the same vein as churches and were eventually replaced by stone buildings in reducciones. In either case, whether wooden or in stone, the break-up with tradition must have been gigantic. Written sources cursorily indicate that children were taught how to read and write, and to play music to celebrate mass, in addition to learning some trades (e.g., Archivum Romanum Societatis Iesu [hereinafter ARSI], Philipp. 13, ff. 248-252; ARSI, Antica Compagnia, Missions, Philipp. 14: 82r; and see also Coello 2011). However, what truly mattered was not so much the content of the teachings, but the fact that a new system of knowledge, and thus of being, followed. In promoting an identification with Jesuit subjectivities, values and worldviews, schools were the most fertile land for coloniality to be ingrained (for a related experience, see Fanon 1952: 120).

At Jesuit schools, oral Chamorro children were converted into literate subaltern Christians. Through reading and writing, new ways of understanding the world and new forms of personhood were forged -a situation that must have been accelerated in those cases where children lived at the very seminaries on a permanent basis (e.g., García 1683: 242). Through disciplines of abstract time and counting - García (1638: 239-240), for instance, praises punctuality and time distribution at seminarios- and by 
fostering focus on the self, a gradual process was brought about that must have promoted a concomitant split into body and mind and favored individuality (see Molina 2013, and Abdi 2007 and Comaroff and Comaroff 1986 for related experiences). In this sense, Jesuits introduced the notion of the body as something separable from the person, and thus the concept of self-objectification (Molina 2013).

Inverting the traditional channels for the transmission of culture -from the oldest to the youngest- missionized children became cultural brokers mediating between new and long-established values and worldviews. In direct opposition to previous parameters, these new values were precisely aimed at depatterning traditional lifeways and promoting change. Inter-generational conflict and/or disagreement were soon to arrive, as portrayed by many episodes in the written sources, including the quote at the beginning of this article (e.g., García 1683: 240; de Aranda 1690: 341). It is also very interesting to note that the foundation of schools ran parallel to the eventual, although very much contested, extermination of "public houses," which were compared and opposed to seminaries in the written sources (e.g., García 1683: 241; Xaramillo 1680, in Lévesque 1996b: 318). It has recently been proposed that conflicts arisen around the burning of schools, churches and "public houses" (e.g., de Aranda 1690: 322-323; García 1683: 512-513) should also be framed within the category of an "ethno-sexual conflict" (Moral de Eusebio 2016).

Of utmost importance, schools acted as powerful engendering locations of the men and women to be. Missionaries had very clear ideas about what constituted gender-appropriate behaviors, values, attitudes and capacities, and an ideal model - although far from operating smoothly even in Europe (e.g., Pobre de Zamora 1598-1603, in Martínez 1997: 446)- of the "correct" asymmetrical relations that should mediate between men and women. Their sexual policies included children's segregation in schools for boys and girls (e.g., García 1683: 510, 512-513), where patriarchal institutions such as the nuclear family or the indissoluble marriage were inculcated, with dramatic consequences for natives' and especially women's lives (on this topic see Segato 2015; Stearns 2006: 70). These also included the active fostering of marriages between boys and girls who had been indoctrinated at these very schools (see also Stearns 2006: 70).

Gender asymmetries were also mobilized in other ways. For instance, although children of both sexes were recruited, priority was given to the construction of schools for boys (e.g., Ledesma 1670: 13v; García 1683: 242). This could easily have promoted a gender-literacy divide in addition to the intergenerational one, and a concomitantly greater male individualization. As phrased by the Comaroffs (1986:15), literacy "may engender a novel perception of the world and the place of the actor within it" (1986: 15). This may also have happened in Guam, where children at schools may have begun to produce an "ordered understanding of their individual history" (Molina 2013: 2) and to consciously identify their sense of self with those features and experiences unique to them (Min-Sun 2001: 6). If more boys than girls attended schools, then different engendered ways of constructing personhood may have resulted, with a greater weight on relationships with others and a stronger corporative self-identification in the case of women (Fowler 2016; Hernando 2002, 2017; Min-Sun 2001). 


\section{In-Carnating Colonialism: New Dresscapes and Corporeal Habits}

Engendering seminaries also targeted corporeal habits and textiles. They were fundamental to disincarnating native customs through new disciplines, technologies and material culture related to dress, clothing and personal adornment. For the Jesuits, dressing the body -with clothes- and the soul -with the Christian doctrine- was part of the same evangelizing process (e.g., García 1683: 162).

Ever since Pigafetta (1524, in de Riquer 1999: 117), the Chamorros' nudity became a commonly highlighted feature in the written sources (e.g., de Aranda 1690: 218; Boxer codex, in Donoso 2016: 7; Coomans 1673, in Lévesque 2000: 8; Rodriguez 1565: 387, 392; Pobre de Zamora 1598-1603, in Martínez 1997: 441, 450; van Noort 1602: 33-34; García 1683: 198), and interpreted as a symptom of barbarity (Ledesma 1670: 3). No textiles other than woven hats and sandals were aimed at dressing the body. Only women over eight-ten years of age covered their pubic areas with Tifis, made of turtle shell or a plant leaf (e.g., Pobre de Zamora 1598-1603, in Martínez 1997: 450; García 1683: 198). Documents mention different hair codes for men and women (e.g., Ledesma 1670: 3v) and specific ornamentation for women at female festivals (e.g., Coomans 1673, in Lévesque 2000: 8-9; García 1683: 200; Ledesma 1670: 3v). In addition, Peter Coomans (1673, in Lévesque 2000: 8) details the arduous process by which women dyed their teeth black. None of these early sources mention any other sexual or social difference in relation to corporeal patterns, a picture that would congruently match low levels of social differentiation, which should have been negotiated through the body and its associated material culture in such oral societies (Fig. 5).

However, archaeological excavations have documented dental modifications and stained red/orange to dark brown teeth probably due to betel chewing only for some bodies (Heatcothe et al. 2012: 147; Ikehara-Quebral and Douglas 1997; Pietrusewsky et al. 2014: 329). Polishing and vertical, diagonal and reticular incising - not mentioned

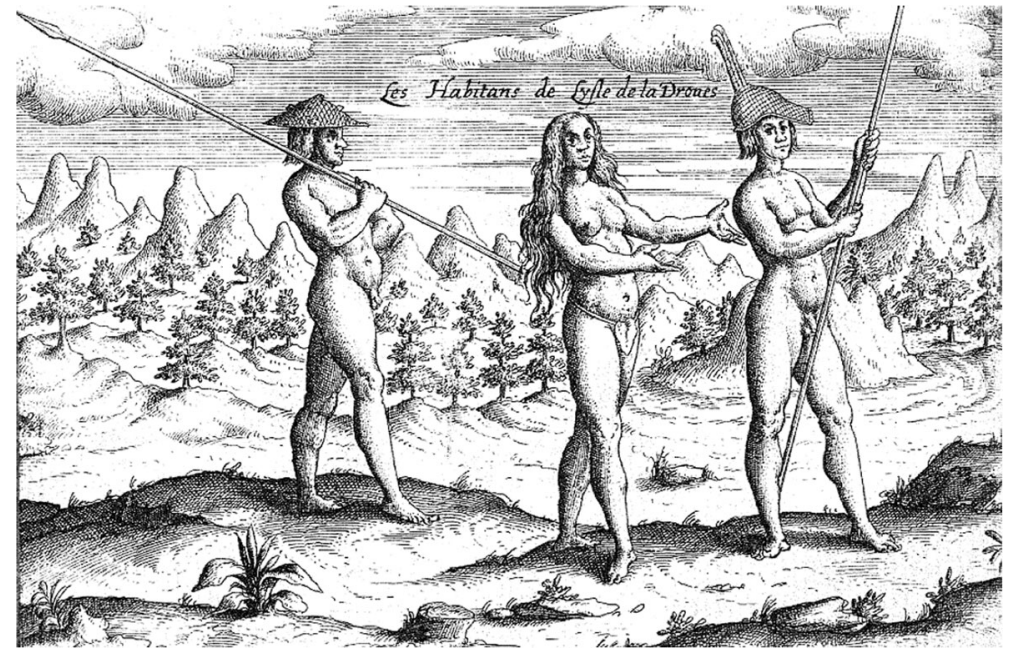

Fig. 5 Seventeenth-century European portrayals of Chamorro people (van Noort 1602: 34) 
in written sources - has also been recorded (Ikehara-Quebral and Douglas 1997; Thompson 1945: 10). At present, no research has successfully established any such thing as a sexual or social pattern. We do know, however, that only a small percentage of skeletons present tooth incising, that they are always adult and that incisions occur in both male and female teeth. Given such a low incidence, they are more likely to be related to a particular group or lineage or to high-ranking members than resulting from rites of passage (Ikehara-Quebral and Douglas 1997: 388).

Archaeological ornaments come in the form of beads and sinahis (Fig. 6). Previously thought to have been a predominantly female feature in burials (e.g., Flores 2011:22), more recent excavations have found that both men and women, as well as adults and children, wore beads (Amesbury and Walth 2016). Archaeological evidence related to cloth is absent. Little wonder that native Chamorro initially mocked European attire (e.g., Pobre de Zamora 1598-1603, in Martínez 1997: 450). In fact, both parts of the equation seem to have been surprised by each other's corporeal codes, but nudity was considered unacceptable by the Jesuits, who treated it with intolerance as well as surprise. The example of Guam adds to those other colonial situations where nudity was seen as equivalent to a lack of civilization that should be urgently brought to the native body in the form of dress (e.g., Comaroff and Comaroff 1986: 14; Loren 2010: 30; Stearns 2006: 70; Voss 2008b: 196), once again, not without native opposition. Francisco García (1683: 222), for instance, notes that Marianos refused to dress for baptism, but that Fray Luis de San Vitores somehow managed to persuade them to do so.

Dressing the body was therefore much more than covering nakedness with garments from abroad. As stated above, in oral societies the self is constructed and represented through material culture and the body in the absence of a conceptual split between mind and body. Bonds with the group are forged and expressed, at a physical level, through a standardization of the body image (Hernando 2002, 2017; Moragón 2013). Foreign dress thus disrobed the native way-of-being in the Mariana Islands. Dress was used as a disciplinary apparatus to disincarnate traditional selves and incarnate new values (modesty, shame, decency, embarrassment, recollection or virtue) in a process where bodies and clothing were intersubjective in configuring new selves (see Molina 2013: 15). Clothing also provided new extra-corporeal materiality to mark and construct the new gender divide promoted by Jesuits, which proposed different codes for men and women. As we have seen, before colonization, differences between men and women were mainly marked with their very bodies. Interestingly enough, the idea that nudity was brought by colonists (Jaulin 1973: 218) becomes especially ductile in the case of Guam.

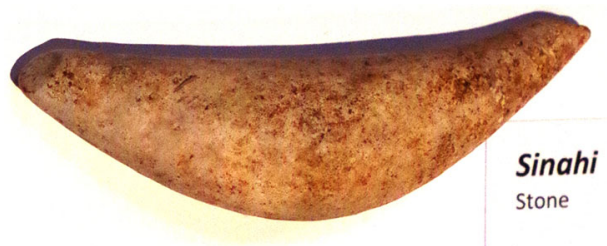

$2017.002 .082 ; B .10,427,8788$

Fig. 6 Archaeological sinahi from the Museum of Guam. Coomans (1673, in Lévesque 2000: 8) mentions that, at their feasts, women slip in a piece of wood in the shape of a half-moon through the left arm, which reminds of the archaeological sinahis documented in other materials. Photograph by Lourdes Prados 
Sources for the contact period situate women in the sphere of textile manufacture, which is however mainly related to house equipment (examples of it being woven palm mats and tables) and funerary ritual (e.g., Pobre de Zamora 1598-1603, in Martínez 1997: 444, 451, and see also Flores 2011: 39). Although Jesuits also saw textiles as the "natural" preserve of women (e.g., de Aranda 1690: 313; AGI, Ultramar, 562: 573r, v), both boys and girls were introduced into their manufacture at schools. In incorporating boys to textile work, the traditional division of labor was disrupted. However, a gender divide was almost immediately reconfigured in the technology used to spin cotton (García 1683: 510): while girls were taught to use spindles (low technology), boys were taught to use lathes (high-technology). Annual letters also report that, at their schools, girls would continue plaiting mats in addition to sewing (e.g., ARSI, Antica Compagnia, Philipp.14, f. 82r).

Although clothes and textile tools were first brought to the island by missionaries and continued being delivered by the Manila Galleons later on (e.g., ARSI, Philipp. 13, ff. 232-234), soon cotton growing was also introduced (e.g., ARSI, Philipp. 13, ff. 250v, and see also Hezel 2015: 201), with obvious repercussions for people's everyday patterns of labor and traditional landscapes. In view of the above, I would like to suggest the concept of dresscape to encapsulate the complex world of interrelationships between the configuration of new selves, values, material culture, landscape and technology that were established in relation to dress, clothing and ornament; and to visualize the consequences that the introduction of clothing must have had on Guam.

\section{Maintenance Activities and the Gender Divide}

Feminist scholars in Guam have already highlighted that Spanish colonization worsened women's social conditions (e.g., Souder 1992). Woefully, Guam is not an isolated case. Feminist and gender studies speak of how women underwent similar processes of disempowerment with the advent of western colonialism in many other parts of the globe (e.g., Allen 1992; Etienne and Leacock 1980; Gautier 2005; Hughes and Hughes 1997; Lugones 2007, 2008; Oyewumi 1997; Segato 2015). A similar downturn in women's lives has also been noted in Europe with the rise of modernity (e.g., Federici 2004; Kelly-Gadol 1977; Mies 1986), which can hardly be taken for a coincidence. It was then that Europe initiated its worldwide expansion, at a moment of patriarchal reaffirmation, propagating the male way of being that was dominant on the continent at the time (Montón-Subías and Hernando 2018), and that concomitantly created and/or aggravated women's subordination both in Europe and at those other places that came under its influence. But in the colonies, the gender subordination of native women was constructed following racial lines in addition to simultaneous gender and class ones (e.g., Lugones 2007; Oyewumi 1997; Segato 2015), a process which also happened in Guam.

As mentioned above, the idea that precontact Chamorros were matrilineal societies where women had stronger power has been taken for granted in the literature of the island and assumed over and over. However, the statement remains both underscrutinized and undertheorized. It is true that literal interpretations of the historical documents may sometimes provoke an image of powerful women versus more vulnerable men, as when we read about marital disputes, where women seem to have enjoyed more rights (e.g., de Aranda 1690: 217-218; Coomans 1673, in Lévesque 
2000: 18; García 1683: 447; Pobre de Zamora 1598-1603, in Martínez 1997: 447). However, we have to bear in mind that patriarchal states were the norm against which Chamorros were measured. In such a context, more equal relations between men and women may well have been misinterpreted as more power for women.

In any case, when sources speak of what has been interpreted as more power for women they usually locate it within the context of the household. However, were there any women among the principales reported by the missionaries? Evidence related to this issue is sparse and vague. For instance, Francisco García (1683: 205) equates principales to some famous matrons (matrona célebre) highlighting the special attention displayed at their funerals (also RAH, Cortes 567 Leg. 10 9/2672, document 8). He also mentions a matron that was governing over the land of Sydia in the way "marianos" govern (1683: 577-578, and see also Souder 1992: 74-75). In a rather ambiguous passage, Pobre de Zamora (1598-1603, in Martínez 1997: 446) explains some of the communal privileges enjoyed by principales, - which he states are called magaraies or macaraies in the native language. And he adds that the same treatment is given to their women. Driver interpreted this passage in her translation of the relation as the wives of principales receiving the same attention and privilege as principales themselves (Driver 1983: 212), but Pobre de Zamora's words could also open up the possibility of the existence of female principales. Some other elements for the discussion are provided by Coomans (1673, in Lévesque 2000: 18 ), who uses the word magahagam (the female of magaraies) to refer to mediators in disputes (see also Flores 2011:26).

However, most mentions to principales in the written sources refer to men. But... does this mean that principales were in fact mainly men, or that Jesuits would not acknowledge women -magahagas- in chief positions? The fact that archaeological excavations have documented secondary burials of female skulls, in addition to male ones, may substantiate the presence of high ranking women (McNeil 2005: 308). In any case, in the current state of evidence - both archaeological and written - I believe it perfectly safe to suppose there was greater equality between precolonial men and women, although the degree and content of this greater equality is yet to be established. It also seems coherent to assume that colonization promoted a gender divide (or a greater one), understanding that gender implies hierarchy and inequality (Scott 1986). Difference may have thus been converted into inequality.

Following the work of Allen, Lugones (2007:199) points out that, during colonialism, the change from more egalitarian to more patriarchal societies is articulated through a set of fundamental mechanisms. These combine the enshrining of a myth of origin with a male creator, the destruction of local institutions, the establishment of the nuclear family at the expense of the matrilineal clan, expulsion from the land and a uniquely male political interlocution. All these conditions seem to have been met in Guam (e.g., Souder 1992: 67-68, 74-77; Thompson 1947: 295). I would add to this list the progressive allocation of Maintenance Activities to women, and their ensuing loss of social recognition. In activating this set, new models of masculinity and femininity were constructed, as well as new gender normativities.

Undoubtedly, Chamorro men also suffered a process of subordination to colonial agents. But the subordination of men was concomitant to gradual empowerment over women: through Catholic marriage, where the subordination of wives was extolled as virtue; through the role played by new forms of kinship; through the creation of a new 
form of indigenous elite which allocated positions of political power only to men; through the fact that it was mainly boys - the cleverest ones - who were handpicked by the Jesuits to spread the Gospel; and - last but not least - through the allocation of maintenance activities to women. Let me reproduce here one of the passages that best encapsulates the new mores expected of the new Christian women:

And what I am to say of the native girls who were married to Spaniards, and Filipinos, who lived contentedly in the presidio and were as fond of Christian ways as if they had been accustomed to them all their lives? They attended Mass everyday and afterward returned to their family obligations, spending their day sewing, washing clothes, and doing other household tasks. ... their constancy and affection for their husbands owed much to the grace of the sacrament of matrimony. All this is to be admired and valued in a land where marriage lasts only so long as the wife wishes it, and where by their own free will, without cause or occasion whatsoever, wives leave their husbands and marry others (García 1683: 561, McDonough 2004: 477 translation, italics are mine).

Faced with this and other similar passages, it is easy to concur with Souder (1992:67) that "Catholicism revolutionized ancient Chamorro conceptions about women" and that a new model of being a woman, the "demure Spanish lady," emerged (Souder 1992: 224). It is also true that the ideal model was just that - an ideal archetype, modified and transgressed in practice in every possible way from sexual abuse of Chamorro women on the part of colonial soldiers to abuse by members of the clergy, as reported in annual letters (e.g., Xaramillo 1680, in Lévesque 1996b: 314-316; and see Coello 2011). But the power of the norm in configuring subjectivities tends to be strong, even for those who consciously transgress it.

Importantly, the previous quote provides also a glaring example of how maintenance activities must have gradually become identified with women's work and associated to the nuclear family and the space occupied by it. In this sense, I agree with Souder (1992:224-225) that the colonization of Guam diminished women's participation in politics on the island and fostered a more specialized sexual division of labor. It seems clear that colonization gendered maintenance activities female. But I will push her argument even further. The changes did not just mean greater specialization in the sexual division of labor, but also less social recognition for maintenance activities, as tends to happen in highly-stratified societies with marked gender inequalities, such as the missionaries' own. First, we must bear in mind that many of the functions previously belonging to the realm of maintenance activities were partly externalized, as has been described above while discussing children's socialization. But, secondly, it must be remembered that maintenance activities are structurally associated to interdependent relationships, to maintaining the group's social bonds and to a lack of social power (González et al. 2008; Hernando 2008; Montón-Subías and Lozano 2012). It should therefore come as no surprise that maintenance activities should have lost social recognition in a context of growing social inequality, as they were cornered into a domestic sphere progressively differentiated from the public realm of power, a dualism which the much more integrated past social reality was split into. 


\section{Conclusion}

On the margins of empire and devoid of the natural riches usually coveted by colonial gluttony, Guam and the Mariana Islands have been considered an atypical, looser case of colonialism, supported by a handful of Jesuits and soldiers, a reduced number of civilians, and resigned governors longing for more propitious destinies. Even the concept of Spanish-Chamorro wars has been challenged under the idea that colonial violence was far away from the grandeur that the concept distills (Hezel 2015). But while for the Spanish colonial powers the colonization of the Marianas might have been a peripheral politico-religious endeavor, I hope to have made it quite clear that for native Chamorro it meant something radically different; from their point of view, the consequences of colonization were as profound as they were structural, because colonization changed their way-of-being in the world. As Souder (1992:233) states, Spanish colonization affected the Chamorro psyche (1992: 233). It can be considered a clear case of coloniality, a phenomenon characteristic of modern colonialism, and which Jesuit missionaries were already seasoned in when they disembarked in Guam.

This article has presented how the colonialization of Guam was activated through the sphere of maintenance activities. Most specifically, I have focused on residential space, children's socialization, and textiles and corporeal habits to show how lifeways were dis-integrated and reconfigured again through targeting maintenance activities. We have seen how reducciones acted as "civilizing" centers, with schools being its most powerful weapon to configure Christian selves and internalize Jesuit cosmovisions. At schools, oral Chamorro children were simultaneously enshrined in clothes and new architecture, and "converted" into literate bodies/minds. Colonialism was thus incarnated through the incorporation of dress codes that promoted both new forms of labor and of domestic technology. Although I have not dealt with them here, other Maintenance Activities such as cooking, hygiene, or the management of public health were also fiercely affected.

Guam is just one of the many examples making up the heterogeneous colonial matrix of early modernity, but I believe that it clearly illustrates the paramount importance of maintenance activities within it. Maintenance activities are fundamental in foregrounding social dynamics. They are aimed at securing traditional lifeways and continuing particular social logics. To implant forcibly a new social coherence, they must be unstructured to be reconfigured again, they cannot remain the same. And this is precisely what Jesuits aimed at in Guam. Through new forms of maintenance activities, new gender routines emerged in the island.

Colonial mission policies were sexual engendering policies. While future studies will need to elucidate whether or not sheer equality between men and women existed in the Latte period, there is no question Jesuits used all the means at their disposal to destructure more equal relations between Chamorro men and women, so alien to and incompatible with their own mindsets. It is also very clear that gender inequality was fostered between Chamorros alongside other forms of social inequality. Oral Chamorros were converted into subaltern literate Chamorros -although the process did not include everybody - and a new (or perhaps the first) sex/gender system emerged. From new forms of landscape to dress, sewing needles, metates, crucifixes, rosary beads, spatial patterns or architecture, new material worlds and daily routines 
followed to construct and represent the new colonial situation, the new gender and social divides, and the new modes of being.

Future analyses will help to outline the trajectories followed by new patterns of Maintenance Activities after 1698. To this goal, excavations must be carried out in colonial enclaves that may act as a robust archaeological counterpoint to the written sources and provide information about everyday life. This is important to understand how new lifeways may have combined with preexistent ones and to verify whether or not the ideals espoused by Jesuits actually percolated the entire population completely, or if they tempered down overtime, as suggested by nineteenth century drawings and descriptions of women farming with their torsos naked (see also Thompson 1947: 47).

In fact, several works have advocated social continuity through Chamorro ethnogenesis and challenged narratives of Chamorro demise (e.g., Atienza and Coello 2012; Diaz 1994; Souder 1992). After five years visiting and excavating annually in Guam, I am well aware that the Chamorro feeling of belonging has arrived to our days in a particular process that has integrated different Oceanian, European and (Latin) American cultural backgrounds. I am a strong supporter of archaeologists seeking for social continuity in colonialism (e.g., Ferris 2009; Flexner et al. 2015; González Ruibal 2013; Rodríguez-Alegría 2014; Mitchell and Scheiber 2010; Hernández 2012; Silliman 2009; Stahl 2012), and I include myself among them (Montón-Subías and Hernando 2018). Still, what I have tried to defend in this work is something different. It is true that Chamorro sentiment has survived to this day, but the traditional oral way of being as the dominant cultural form on the island of Guam vanished forever with missionization and the introduction of schools and literacy.

Acknowledgments Heartfelt thanks go to Verónica Peña Filiu and Enrique Moral de Eusebio for their support and helpful suggestions while writing the first draft of this paper. I would also like to thank James Bayman, Omaira Brunal-Perry, Boyd Dixon, David Atienza, Darlene Moore, Judy Amesbury, Mike Carson and Sandy Yee for their answers to specific questions related to archival and archaeological evidence. Finally, thanks to Natalia Moragas and Laura Trelliso for comments on the first manuscript submitted to IJHA. Any errors or shortcomings, however, are my own responsibility. Pedro Pablo Fermin Maguire and an anonymous reviewer made my English much better.

This article was written with the support of the Spanish Ministry of Economy and Competitiveness under Grant HAR2016-77564-C2-1-P.

Open Access This article is distributed under the terms of the Creative Commons Attribution 4.0 International License (http://creativecommons.org/licenses/by/4.0/), which permits unrestricted use, distribution, and reproduction in any medium, provided you give appropriate credit to the original author(s) and the source, provide a link to the Creative Commons license, and indicate if changes were made.

\section{References}

Abdi, A. (2007). Oral societies and colonial experiences: sub-saharan Africa and the de facto power of the written word. International Education 37(1): 42-59.

Allen, P. (1992). The Sacred Hoop. Recovering the Feminine in American Indian Traditions. Beacon, Boston. Amesbury, J. and Walth, C. (2016). Who Wears the Beads? 2000 Years of Ornaments from an Archaeological Site on Guam. Guam Preservation Trust, Hagåtña.

Aram, B. and Yun-Casalilla, B. (eds.) (2016). Global Goods and the Spanish Empire, 1492-1824: Circulation, Resistance and Diversity. Palgrave Macmillan, London. 
Athens, J. S., Dega, M. F., and Ward, J. V. (2004). Austronesian colonisation of the Mariana Islands: the palaeoenvironmental evidence. Bulletin of the Indo-Pacific Prehistory Association 24: 21-30.

Atienza, D. and Coello, A. (2012). Death rituals and identity in contemporary Guam (Mariana Islands). The Journal of Pacific History 47(4): 459-473.

Banchoff, T. and Casanova, J. (eds.) (2016). The Jesuits and Globalization: Historical Legacies and Contemporary Challenges. Georgetown University Press, Washington, DC.

Bayman, J. and Peterson, J. (2016). Spanish colonial history and archaeology in the Mariana Islands: echoes from the Western Pacific. In Montón Subías, S., Cruz Berrocal, M., Ruiz, A. eds., Archaeologies of Early Modern Spanish Colonialism. Springer, New York, pp. 229-252.

Bayman, J., Kurashina, H., Carson, M., Peterson, J., Doig, D., and Drengson, J. (2012a). Household economy and gendered labor in the 17th century AD in the Mariana Islands, western Pacific. Journal of Field Archaeology 37: 259-269.

Bayman, J., Kurashina, H., Carson, M., Peterson, J., Doig, D., and Drengson, J. (2012b). Latte household economic organization at Ritidian, Guam National Wildlife Refuge, Mariana Islands. Micronesica: A Journal of the University of Guam 42(1/2): 258-273.

Bertelsen, R., Lillehammer, A., and Næss, J. (eds.) (1987). Were They All Men? An Examination of Sex Roles in Prehistoric Society. Arkeologist museum i Stavenger, Stavenger.

Bourdieu, P. (1972). Esquisee d'une théorie de la practique, précédé de trois études d'ethnologie kabyle. Droz, Geneva.

Bourdieu, P. (1990). Time Perspectives of the Kabyle. In Hassard, J. ed., The Sociology of Time. St. Martin's Press, New York, pp. 219-237.

Brunal-Perry, O. (2009). Early European Exploration and the Spanish Period in the Marianas 1521-1898. In Carrell, T. ed., Maritime history and archaeology of the Commonwealth of the Northern Mariana Islands. CNMI Division of Historic Preservation, Saipan, pp. 95-142.

Carson, M. (2012). An overview of latte-period archaeology. Micronesica 42: 1-79.

Carson, M. (2014). Paleo-terrain research: finding the first settlement sites of remote Oceania. Geoarchaeology 29: 268-275.

Clossey, L. (2008). Salvation and Globalization in the Early Jesuit Mission. CUP, Cambridge.

Coello, A. (2011). Colonialismo y santidad en las islas marianas: la sangre de los mártires (1668-1676). Hispania Sacra 63(128): 707-745.

Coello, A., Burrieza, J., and Moreno, D. (2012). Introducción. In Coello, A., Burrieza, J., Moreno, D. eds., Jesuitas e Imperios de Ultramar. Siglos XVI-XX. Sílex, Madrid, pp. 11-31.

Comaroff, J., and Comaroff, J. (1986). Christianity and colonialism in South Africa. American Ethnologist 13(1): 1-22.

Conkey, M., and Gero, J. (1991). Tensions, Pluralities, and Engendering Archaeology: An Introduction to Women and Prehistory. In Gero, J., Conkey, M. eds., Engendering Archaeology. Women and Prehistory. Basil Blackwell, Oxford, pp. 3-30.

Connah, G. (1998). Pattern and purpose in historical archaeology. Australasian Historical Archaeology 16: 3-7.

Cordy, R. (1983). Social stratification in the Mariana Islands. Oceania 53: 272-276.

Craib, J. (1986). Casa de los antiguos: Social differentiation in protohistoric Chamorro society. Doctoral dissertation. University of Sydney, Sydney.

Dampier, W. (1697). A New Voyage Round the World. James Knapton, London.

de Aranda, G. (1690). Vida y gloriosa muerte del venerable Padre Sebastián de Monroy, religioso de la Compañia de Jesús, que murió dilatando la fe alanceado de los bárbaros de las Islas Marianas. Thomas López de Haro, Sevilla.

de Riquer, I. (1999). Antonio Pigafetta. El primer viaje alrededor del mundo: Relato de la expedición de Magallanes y Elcano. Ediciones B, Barcelona.

Deagan, K. (1974). Sex, Status, and Role in the Mestizaje of Spanish Colonial Florida. Doctoral dissertation. University of Florida, Gainesville.

Diaz, V. (1994). Simply Chamorro: telling tales of demise and survival in Guam. The Contemporary Pacific 6(2): 29-58.

Dixon, B. and Gilda, L. (2011). A comparison of an inland latte period community to coastal settlement patterns observed on southern Guam. People and Culture of Oceania 27: 65-86.

Dixon, B., Mangieri, T., McDowell, E., Paraso, K., and Rieth, T. (2006). Prehistoric Chamorro household activities and refuse disposal patterns on the Micronesian Island of Tinian, Commonwealth of the Northern Mariana Islands. Micronesica 31(1): 55-71.

Dixon, B., Schaefer, R., and McCurdy, T. (2010). Traditional farming innovations during the Spanish and Philippine contact period on northern Guam. Philippine Quarterly of Culture and Society 38(4): 291-321. 
Dixon, B., Craft, C., and Jalandoni, A. (2017). The archaeological remains of early modern Spanish colonialism on Guam and their implications. In Cruz, M. and Tsang, C. (eds.), Historical Archaeology of Early Modern Colonialism in Asia-Pacific: The Asia-Pacific Region. University Press of Florida, Gainesville, pp. 195-218.

Donoso, I. (2016). Boxer Codex. A Modern Spanish Transcription and English Translation of 16th-Century Exploration Accounts of East and Southeast Asia and the Pacific. Vibal Bookstore, Quezon City.

Driver, M. (1983). Fray Juan Pobre de Zamora and his account of the Mariana Islands. The Journal of Pacific History 18(3): 198-216.

Etienne, M. and Leacock, E. (eds.) (1980). Women and Colonization. Praeger, New York.

Fanon, F. (1952). Peau noire, masques blancs. Éditions du Seuil, Paris.

Farrell, D. (2011). History of the Mariana Islands to Partition. Public School System, CNMI, Saipan.

Federici, S. (2004). Caliban and the Witch: Women, the Body, and Primitive Accumulation. Autonomedia, New York.

Ferris, N. (2009). The Archaeology of Native-Lived Colonialism: Challenging History in the Great Lakes. University of Arizona Press, Tucson.

Flexner, J., Willie, E., Lorey, A., Alderson, H., Williams, R., and Ieru, S. (2015). Iarisi's domain: historical archaeology of a Melanesian Village, Tanna Island, Vanuatu. Journal of Island and Coastal Archaeology 11: $26-49$.

Flores, J. (2011). Estorian Inalahan. History of a Spanish-era Village in Guam. Irensia, Hagåtña.

Fowler, C. (2016). Relational personhood revisited. Cambridge Archaeological Journal 26: 397-412.

Fredericksen, C. (2000). History and prehistory: essential dichotomy or arbitrary separation? Australian Archaeology 50: 94-97.

García, F. (1683). Vida y Martirio del Venerable Padre Diego Luis de San Vitores. Imprenta de Juan García Infanzón, Madrid.

Gautier, A. (2005). Mujeres y colonialismo. In Ferro, M. (ed.), El libro negro del colonialismo. Siglos XVI al XXI: Del exterminio al arrepentimiento. La esfera de los libros, Madrid, 677-723.

Giráldez, A. (2015). The Age of Trade: The Manilla Galleons and the Dawn of the Global Economy. Rowman and Littlefield, Lanham.

González-Ruibal, A. (ed.) (2013). Reclaiming Archaeology. Beyond the Tropes of Modernity. Routledge, London.

González-Ruibal, A., Hernando, G., and Politis, G. (2011). Ontology of the self and material culture: arrowmaking among the Awá hunter-gatherers (Brazil). Journal of Anthropological Archaeology 30: 1-16.

González, P., Montón-Subías, M., and Picazo, M. (2008). Towards an archaeology of maintenance activities. In Montón-Subías, S. and Sánchez Romero, M. (eds.), Engendering Social Dynamics: The Archaeology of Maintenance Activities. Archaeopress, Oxford, pp. 3-8.

Goody, J. (2006). The Theft of History. Cambridge University Press, Cambridge.

Graves, M. (1986). Organization and differentiation within late prehistoric ranked social units, Mariana Islands, western Pacific. Journal of Field Archaeology 13: 139-154.

Gruzinski, S. (2004). Les quatre parties du monde: Histoire d'une mundialization. Editions de la Martinière, Paris.

Gruzinski, S. (2012). L'aigle et le dragon: Démesure européenne et mondialisation au XVIe siècle. Fayard, Paris.

Havelock, E. (1988). The Muse Learns to Write: Reflections on Orality and Literacy from Antiquity to the Present. Yale University Press, New Haven.

Heatcothe, G., Diego, V., Ishida, H., and Sava, V. (2012). An osteobiography of a remarkable protohistoric Chamorro man from Taga, Tinian. Micronesica 43(2): 131-213.

Hendon, J. (1996). Archaeological approaches to the organization of domestic labor: household practice and domestic relations. Annual Review of Anthropology 25: 45-61.

Hernández G. (2012). Ceramics and the Spanish Conquest: Response and Continuity of Indigenous Pottery Technology in Central Mexico. Brill, Leiden, Boston.

Hernando, A. (2002). Arqueología de la Identidad. Akal, Madrid.

Hernando, A. (2008). Why has history not appreciated maintenance activities? In Montón-Subías, S. and Sánchez Romero, M. (eds.), Engendering Social Dynamics: The Archaeology of Maintenance Activities. Archaeopress, Oxford, pp. 9-14.

Hernando, A. (2017). The Fantasy of Individuality: On the Sociohistorical Construction of the Modern Subject. Springer, New York.

Hezel, F. (1989). From Conquest to Colonization: Spain in the Mariana Islands 1690 to 1740. M.P: Division of Historic Preservation, Saipan. 
Hezel, F. (2015). When Cultures Clash: Revisiting the "Spanish-Chamorro Wars." The Northern Marianas Humanities Council, Saipan.

Hornbostel, H. (1924-25). Unpublished notes from the Bernice P. Bishop Museum, Honolulu. Micronesian Area Research Center, University of Guam, Mangilao.

Hughes, S. and Hughes, B. (1997). Women in World History: Readings from 1500 to the Present. Vol. 2. M.E. Sharpe, Armonk, NY.

Hunter-Anderson, R. (2011). The Latte Period in Marianas prehistory: who is interpreting it, why and how? In Liston, J., Clark, G., and Alexander, D. (eds.), Archaeology, Identity, and Community. Australian National University, Canberra, 17-29.

Hunter-Anderson, R. and Butler, M. (1995). An Overview of Northern Marianas Prehistory. Micronesian Archaeological Survey Report, Saipan.

Ikehara-Quebral, R. and Douglas, M. T. (1997). Cultural alteration of human teeth in the Mariana Islands. American Journal of Physical Anthropology 104: 381-391.

Jaulin, R. (1973). La paz blanca: Introducción al etnocidio. Tiempo Contemporaneo, Buenos Aires.

Kelly-Gadol, J. (1977). Did women have a reinassence? In Bridenthai, R. and Coonz, C. (eds.), Becoming Visible: Women in European History. Houghton Mifflin, Boston, pp. 175-201.

Kerr, A. (2013). Estevan Rodriguez's (1565 in Academia Real 1886). La Manera de su Hablar: The First Lexicon of the Chamorro Language, Mariana Islands, Micronesia. University of Guam, Marine Laboratory Technical Report 153, Manguilao.

Kurashina, H. and Clayshulte R. (1983). Site formation processes and cultural sequence at Tarague, Guam. Bulletin of Indo-Pacific Prehistory Association 4: 114-122.

Laguana, A., Kurashina, H., Carson, M., Peterson, J., Bayman, J., Ames, T., Stephenson, R., Aguon, J., and Harya Putra, I. (2012). Estorian i latte: a story of latte. Micronesica 42(1/2): 80-120.

Lander, E. ed. (2000). La colonialidad del saber: eurocentrismo y ciencias sociales. Perspectivas lationoamericanas. CLASCO, Buenos Aires.

Ledesma, X. (1670). Noticias de los Progresos de Nuestra Santa Fe en las Islas Marianas. Biblioteca del Hospital Real de Granada/Caja IMP-2-070 (31) Col. Montenegro.

Lefébvre, H. (1974). La Production de l'Espace. Édition Anthropos, Paris.

Lévesque, R. (ed.) (1996a). History of Marianas: A Collection of Source Documents. Volume 7-More Turmoil in the Marianas 1679-1683. Lévesque, Québec.

Lévesque, R. (ed.) (1996b). History of Marianas: A Collection of Source Documents. Lévesque, Québec.

Lévesque, R. (ed.) (2000). History of the Mision in the Mariana Islands by Fr. Peter Coomans. CNMI Division of Historic Preservation, Saipan.

Lightfoot, K. (1995). Culture contact studies: redefining the relationship between prehistoric and historical archaeology. American Antiquity 60: 199-217.

Lightfoot, K. (2005). Indians, Missionaries, and Merchants: The Legacy of Colonial Encounters on the California Frontiers. University of Calfornia Press, Berkeley.

Little, B. (1994). People with history: an update on historical archaeology in United States. Journal of Archaeological Method and Theory 1(1): 5-40.

Loren, D. (2010). The Archaeology of Clothing and Bodily Adornment in Colonial America. University Press of Florida, Gainesville.

Low, S. and Lawrence-Zuñiga, D. (eds.) (2003). The Anthropology of Space and Place: Locating Culture. Wiley-Blackwell, London.

Lugones, M. (2007). Heterosexualism and the colonial/modern gender system. Hypatia 22(1): 186-209.

Lugones, M. (2008). Colonialidad y Género. Tábula rasa 9: 73-101.

Maldonado-Torres, N. (2007). On the coloniality of being. Cultural Studies 21(2-3): 240-270.

Marks, R. (2002). The Origins of the Modern World: A Global and Ecological Narrative from the Fifteenth to the Twenty-First Century. Rowman and Littlefield, Lanham.

Martínez, J. (1997). Fray Juan Pobre de Zamora. Historia de la Pérdida y Descubrimiento del Galeón "San Felipe". Diputación Provincial de Ávila, Ávila.

Massey, D. B. (1994). Space, Place and Gender. University of Minnesota Press, Minneapolis.

McDonough, J. ed. (2004). The life and martyrdom of the venerable father Diego Luis de San Vitores of the Society of Jesus. Richard Flores Taitano Micronesian Area Research Center, University of Guam, Manguilao.

McNeil, J. (2005). Putting the Dead to Work. An Examination of the Use of Human Bone in Prehistoric Guam. In Rakita, G., Buikstra, J., and Beck, L. (eds.), Interacting with the dead: Perspectives on Mortuary Archaeology for the New Millenium. University Press of Florida, Gainsville, pp. 305-315.

Mies, M. (1986). Patriarchy and Accumulation on a World Scale. Zed Books, London and New York.

Millet, K. (1972). Sexual Politics. Abacus, London. 
Min-Sun, K. (2001). Perspectives on Human Communication. Implications for Transculture Theory. In Transcultural Realities. In Milhouse, V., Asante, M., and Nwosu, P. (eds.), Interdisciplinary Perspectives on Cross-Cultural Relations. Sage, London, pp. 3-31.

Mitchell, M. and Scheiber, L. (2010). Crossing Divides. Archaeology as Long-Term History. In Scheiber, L. and Mitchell, M. (eds.), Across a Great Divide, Continuity and Change in Native North American Societies, 1400-1900. University of Arizona Press, Tucson, pp. 1-22.

Molina, M. (2013). To Overcome Oneself. The Jesuit Ethic and Spirit of Global Expansion, 1520-1767. University of California Press, Berkeley, Los Angeles and London.

Montón-Subías, S. and Hernando, A. (2018). Modern colonialism, eurocentrism and historical archaeology: some engendered thoughts. European Journal of Archaeology 21 (3), in press.

Montón-Subías, S. and Lozano, S. (2012). La arqueología feminista en la normatividad académica. Complutum 23: pp. 163-176.

Montón-Subías, S. and Sánchez Romero, M. (2008). Engendering Social Dynamics. The Archaeology of Maintenance Activities. Archaeopress, Oxford.

Montón-Subías, S., Bayman, J., and Moragas, N. (2018). Arqueología del colonialismo español en la Micronesia: Guam y las Poblaciones Chamorras. In Marín-Aguilera, B. (ed.), Repensar el colonialismo: Iberia, de colonia a potencia colonial. JAS, Madrid, pp. 303-336.

Moragón, L. (2013). Cuerpo y sociedades orales. Una reflexión sobre la concepción del cuerpo y sus implicaciones en el estudio de la Prehistoria. Unpublished PhD. Madrid, Universidad Complutense de Madrid.

Moral de Eusebio, E. (2016). Heterotopías en conflicto: sexualidad, colonialismo y cultura material en las Islas Marianas durante el siglo XVII. In Coelho, I. P., Torres, J., Serrão, L., and Ramos, T. (eds.), Entre ciência e cultura: Da interdisciplinaridade à transversalidade da arqueología (Actas das VIII Jornadas de Jovens em Investigação Arqueológica). CHAM, IEM, Lisboa, pp. 229-232.

Olson, D. (1986). The cognitive consequences of literacy. Canadian Journal of Psychology 27(2): 109-121.

Olson, D. (1996). The World on Paper: The Conceptual and Cognitive Implications of Writing and Reading. Cambridge University Press, Cambridge.

Ong, W. (1982). Orality and Literacy. The Technologizing of the Word. Routledge, New York.

Oyewumi, O. (1997). The Invention of Women: Making an African Sense of Western Gender Discourses. University of Minnesota Press, Minneapolis.

Panich, L. and Schneider, T. (eds.) (2014). Indigenous Landscapes and Spanish Missions: New Perspectives from Archaeology and Ethnohistory. University of Arizona Press, Tucson.

Peterson, J. (2012). Latte villages in Guam and the Marianas: monumentality or monumenterity? Micronesica 42: $183-208$.

Picazo, M. (1997). Hearth and home: the timing of maintenance activities. In Moore, J. and Scott, E. (eds.), Invisible People and Processes: Writing Gender and Childhood in European Archaeology. Leicester University Press, London, pp. 59-67.

Pietrusewsky, M., Douglas, M., Swift, M., Harper, R., and Fleming, M. (2014). Health in ancient Mariana islanders: a bioarchaeological perspective. Journal of Island and Coastal Archaeology 9(3): 319-340.

Prosperi, A. (1992). L'Europa Cristiana e i el mondo: alle origine dell'idea di missione. Dimensioni e problemi della ricerca storica 2/1999: 189-220.

Quijano, A. (2000). Coloniality of power, eurocentrism, and Latin America. Nepentla: Views From the South 1(3): 533-580.

Reinman, F. (1966). Notes on an Archaeological Survey of Guam, Mariana Islands, 1965-1966. Preliminary Report National Science Foundation Grant \#GS-662. Unpublished manuscript. Micronesian Area Research Center, University of Guam, Manguilao.

Rodríguez-Alegría, E. (2014). A paradox in colonialism and technological change. Revista de Arqueología Americana 32: 7-26.

Rubiés, J. (2017). Ethnography and cultural translation in the early modern missions. Studies in Church History 53: 272-310.

Russell, S. (1998). Tiempon I Manmofo'na: Ancient Chamorro Culture and History of the Northern Mariana Islands. División of Historic Preservation, Saipan.

San Vitores, L. (1671). Extracto de la carta del Siervo de Dios ak Procurador P. Jose Vidal para que interceda con la Reina por dos dos seminarios de niños y niñas de Guam, 25 de mayo de 1671. In Officium Historicum, Sacra Congregatio Pro Causis Sanctorum. Mailen. Seu Aganien. Beatificationis Seu Declarationis Martyrii Servi Dei Didaci Aloisii De San Vitores, Sacerdotis Professi Societatis Iesu, 1672. Position Super Vita Et Martyrio Ex Officio Concinnata, Romae 1981: 221-214.

Scott, J. W. (1986). Gender: a useful category of historical analysis. American Historical Review 91(5): 10-53. 
Segato, R. (2015). Género y colonialidad: del patriarcado comunitario de baja intensidad al patriarcado colonial moderno de alta intensidad. In Segato, R. (ed.), La crítica de la colonialidad en ocho ensayos: Y una antropología por demanda. Prometeo, Buenos Aires, pp. 69-99.

Selwyn, J. (2004). A Paradise Inhabited by Devils: The Jesuits' Civilizing Mission in Early Modern Naples (Catholic Christendom, 1300-1700). Routledge, London.

Silliman, S. (2001). Theoretical perspectives on labor and colonialism: reconsidering the California missions. Journal of Anthropological Archaeology 20(4): 379-407.

Silliman, S. (2009). Change and continuity, practice and memory: Native American persistence in colonial New England. American Antiquity 74: 211-230.

Soja, E. (1993). Postmodern Geographies: The Reassertion of Space in Critical Social Theory. Verso, London and New York.

Souder, L. (1992). Daughters of the Island: Contemporary Chamorro women organizers of Guam. University Press of America, Lanham.

Stahl, A. (2012). When does history begin? material continuity and change in West Africa. In Hart, O. and Frink, L. (eds.), Decolonizing Indigenous Histories: Exploring Prehistoric/Colonial Transitions in Archaeology. University of Arizona Press, Tucson, pp. 158-177.

Stearns, P. (2006). Gender in World History. Routledge, New York.

Stodder, A., Ryan, E., Hunter-Anderson, R., Douglas, M., and Ikehara-Quebral, R. (2015). Under the latte: osteobiography and social context of a burial assemblage at Tumon Bay, Guam. In Oxenham, M. and Buckley, H. (eds.), The Routledge Handbook of Bioarchaeology in Southeast Asia and the Pacific Islands. Routledge, New York, pp. 527-568.

Tarble de Scaramelli, K. (2011). Effects of the empire: gendered transformations in the Orinico frontier. In Voss, B. and Casella, E. (eds.), The Archaeology of Colonialism: Intimate Encounters and Sexual Effects, Cambridge University Press, Cambridge, pp. 138-155.

Thompson, L. (1940). The Function of Latte in the Marianas. Journal of the Polynesian Society 49(195): 449465.

Thompson, L. (1945). The Native Cultures of the Mariana Islands. Bernice P. Bishop Museum, Honolulu.

Thompson, L. (1947). Guam and its People. Princeton University Press, Princeton.

Thornton, R. (1980). Space, Time and Culture among the Iraqw of Tanzania. Academic Press, New York.

Tringham, R. (1991). Household with faces: the challenge of gender in prehistoric architectural remains. In Gero, J. and Conkey, M. (eds.), Engendering Archaeology: Women and Prehistory. Basil Blackwell, Oxford, pp. 93-131.

Van Noort, O. (1602). Description du penible voyage faict entour de l'univers ou globe terrestre. Chez Corneille Nicolas, Amsterdam.

Van Valkenburg, P. (2017). Historias galonadas: la genealogía de reducción, paisaje y población en los valles de Zaña y Chamán, Perú. In Saito, A., Rosas Lauro, C. eds., Reducciones. La concentración forzada de las poblaciones indígenasen el Virreinato del Perú. Fondo Editorial, Lima, pp. 223-259.

Voss, B. (2008a). Gender, race and labor in the archaeology of the Spanish colonial America. Current Anthropology 4: 861-893.

Voss, B. (2008b). Domesticating imperialism: sexual politics and the archaeology of empire. American Anthropologist 110: 191-203.

Wallerstein, I. (1974). The Modern World System: Capitalist Agriculture and the Origins of the European World Economy in the Sixteenth Century. Academic Press, San Diego.

Wernke, S. (2012). Andean households in transition: the politics of domestic space at an early colonial Doctrina in the Peruvian highlands. In Oland, M., Hart, S., and Frink, L. (eds.), Decolonizing Indigenous Histories Exploring Prehistoric/Colonial Transitions in Archaeology. University of Arizona Press, Tucson, pp. 201-229.

Wilkie, L. (2005). Inessential archaeologies: problems of exclusion in Americanist archaeological thought. World Archaeology 37(3): 337-351.

Zuluaga, M. (2014). The process of Reducciones among Muisca peoples in Santafé during the 16th and 17th centuries. Historia Crítica 52: 179-203. 